\title{
ALDOSTERONE AND 17-HYDROXYCORTICOSTEROID EXCRETION FOLLOWING RAMSTEDT'S OPERATION
}

\author{
BY \\ WILLIAM HAMILTON \\ From the University Department of Child Health and the Royal Hospital for Sick Children, Glasgow
}

(RECEIVED FOR PUBLICATION NOVEMBER 5, 1964)

The management of infants with pyloric stenosis has local variations. In this department a régime of simplicity has been adopted in which the patient is disturbed as little as possible. The diagnosis is made on palpation of a pyloric 'tumour' during a test feed, and only rarely is diagnostic assistance sought from a barium meal.

A gastric lavage is done not less than four hours before operation. Pyloromyotomy is performed under general or local anaesthesia according to the surgeon's preference and the child is returned to the medical ward. Feeding is recommenced 4 hours after operation with $8 \mathrm{ml}$. half-cream National Dried Milk alternating hourly with half-strength physiological saline in unrestricted quantities. The volume of milk is gradually increased and also the interval between feeds until on the third post-operative day $45 \mathrm{ml}$. milk is being given 4-hourly. Water at this stage is given instead of saline. On subsequent days the volume of each milk feed is increased by $15 \mathrm{ml}$. until an appropriate full feed is reached. The child is discharged on the 5th post-operative day and returns on the 12th day for removal of sutures. Breast-fed infants are given expressed breast milk and allowed home usually on the 2 nd postoperative day to continue breast-feeding. The sutures are also removed on the 12th post-operative day.

Biochemical studies are not done routinely and parenteral fluid and electrolyte replacements are undertaken only in the infrequent cases in which dehydration is severe.

During the past 4 years 58 cases, on average, have been treated annually in this unit with one death (a mortality rate of less than $0.5 \%$ ).

The present study was designed to assess the adrenocortical response to the acute stress of pyloromyotomy as measured by the urinary 17hydroxycorticosteroid excretion, and to determine the level of free aldosterone excretion in infants.

\section{Material and Methods}

The series comprises 27 male infants with pyloric stenosis admitted to the Royal Hospital for Sick Children, Glasgow. Each child had, on admission, a length of $\frac{1}{2}$ in. $(1 \cdot 27 \mathrm{~cm}$.) wide Paul's tubing secured over the penis with 'Sleek'. The free end was knotted and the urine which collected was transferred at intervals to suitable containers. Five consecutive 24-hour urine collections were made using chloroform as preservative. Urinary 17hydroxycorticosteroids (17-OHCS) were estimated by Few's (1961) method. Recovery rates were consistently over $80 \%$ using cortisol as a model compound. Aldosterone was measured by soda-fluorescence using Brooks' (1960) technique. Recovery rates ranged from 38 to $77 \%$. The fluorimetric readings for standard aldosterone diacetate were linear in the range 0.5 to $2 \cdot 0 \mu \mathrm{g}$.

\section{Results and Discussion}

17-Hydroxycorticosteroids. In non-stressful conditions the pituitary and adrenal cortex act together to maintain optimal plasma cortisol levels. This mechanism is altered during major surgical procedures. Under such stress the pituitary gland continues to secrete ACTH despite a rise in plasma cortisol. An increased urinary excretion of 17-OHCS follows (Tyler, Schmidt, Eik-Nes, Brown, and Samuels, 1954).

In Table 1 the daily urinary 17-OHCS excretion in 12 male infants following pyloromyotomy is shown. Depending on the time of admission of the individual case, pyloromyotomy might have been performed at any time within 24 hours of admission. Any increase in adrenocortical secretion due to the operation in such cases might, therefore, increase the output of urinary 17-OHCS within the first 24 hours. Except for Cases 1 and 3, those with a first day excretion greater than $1 \mathrm{mg}$. 17-OHCS had the operation within 24 hours of admission. Cases 1 to 8 excreted more than $5 \mathrm{mg}$. 17-OHCS/24 hours on at least one day in the post-operative period. In Cases 
TABLE 1

URINARY 17-HYDROXYCORTICOSTEROID IN CASES OF PYLORIC STENOSIS TREATED BY RAMSTEDT OPERATION

\begin{tabular}{|c|c|c|c|c|c|c|c|c|c|c|c|}
\hline \multirow[b]{2}{*}{ Case } & \multirow{2}{*}{$\begin{array}{c}\text { Age } \\
\text { (wk.) }\end{array}$} & \multirow{2}{*}{$\begin{array}{c}\text { Duration } \\
\text { of } \\
\text { Vomiting }\end{array}$} & \multirow{2}{*}{$\begin{array}{c}\text { Birth } \\
\text { Weight } \\
\text { (kg.) }\end{array}$} & \multirow{2}{*}{$\begin{array}{c}\text { Admission } \\
\text { Weight } \\
\text { (kg.) }\end{array}$} & \multirow[b]{2}{*}{ Anaesthetic } & \multicolumn{5}{|c|}{ Urinary 17-hydroxycorticosteroids (mg./24 hr.) } & \multirow{2}{*}{$\begin{array}{c}\text { Maximum } \\
\text { Daily } \\
\text { Excretion } \\
\text { (mg./kg. } \\
\text { day) }\end{array}$} \\
\hline & & & & & & 1 & 2 & 3 & 4 & 5 & \\
\hline $\begin{array}{r}1 \\
2 \\
3 \\
4 \\
5 \\
6 \\
7 \\
8 \\
9 \\
10 \\
11 \\
12\end{array}$ & $\begin{array}{l}9 \\
4 \\
4 \\
8 \\
8 \\
4 \\
4 \\
4 \\
3 \\
2 \\
7 \\
5\end{array}$ & $\begin{array}{c}6 \text { wk. } \\
4 \text { wk. } \\
2 \text { wk. } \\
6 \text { wk. } \\
3 \text { wk. } \\
2 \text { wk. } \\
7 \text { dy. } \\
8 \text { dy. } \\
10 \text { dy. } \\
6 \text { dy. } \\
7 \text { dy. } \\
10 \text { dy. }\end{array}$ & $\begin{array}{l}3 \cdot 2 \\
3 \cdot 2 \\
2 \cdot 86 \\
2 \cdot 72 \\
3 \cdot 5 \\
3 \cdot 2 \\
2 \cdot 44 \\
3 \cdot 4 \\
2 \cdot 58 \\
3 \cdot 3 \\
3 \cdot 85 \\
3 \cdot 68\end{array}$ & $\begin{array}{l}4 \cdot 0 \\
3 \cdot 34 \\
3 \cdot 2 \\
3 \cdot 12 \\
5 \cdot 0 \\
3 \cdot 2 \\
2 \cdot 64 \\
3 \cdot 56 \\
2 \cdot 15 \\
3 \cdot 02 \\
3 \cdot 45 \\
3 \cdot 42\end{array}$ & $\begin{array}{c}\text { General } \\
\text { General } \\
\text { General } \\
\text { General } \\
\text { General } \\
\text { General } \\
\text { Local } \\
\text { General } \\
\text { General } \\
\text { Local } \\
\text { General } \\
\text { General }\end{array}$ & $\begin{array}{r}1.8 \\
* 1.5 \\
1.9 \\
* 1.2 \\
0.7 \\
0.4 \\
* 3.4 \\
0.8 \\
* 1.6 \\
0.5 \\
* 1.2 \\
0.3\end{array}$ & $\begin{array}{l}7 \cdot 1 \\
6 \cdot 4 \\
7 \cdot 4 \\
6 \cdot 1 \\
5 \cdot 5 \\
6 \cdot 5 \\
5 \cdot 8 \\
5 \cdot 6 \\
0 \cdot 7 \\
1 \cdot 8 \\
3 \cdot 1 \\
3 \cdot 6\end{array}$ & $\begin{array}{l}4 \cdot 8 \\
4 \cdot 2 \\
7 \cdot 1 \\
3 \cdot 5 \\
0 \cdot 6 \\
1 \cdot 3 \\
2 \cdot 6 \\
2 \cdot 0 \\
1 \cdot 3 \\
1 \cdot 9 \\
3 \cdot 9 \\
2 \cdot 1\end{array}$ & $\begin{array}{l}4 \cdot 3 \\
4 \cdot 4 \\
4 \cdot 3 \\
2 \cdot 3 \\
1 \cdot 2 \\
1 \cdot 3 \\
4 \cdot 0 \\
1 \cdot 6 \\
2 \cdot 8 \\
3 \cdot 6 \\
2 \cdot 2 \\
2 \cdot 3\end{array}$ & $\begin{array}{l}1 \cdot 9 \\
1 \cdot 2 \\
2 \cdot 1 \\
1 \cdot 3 \\
0 \cdot 8 \\
- \\
2 \cdot 6 \\
1 \cdot 6 \\
3 \cdot 4 \\
2 \cdot 4 \\
2.0 \\
-\end{array}$ & $\begin{array}{l}1 \cdot 77 \\
1.91 \\
2 \cdot 3 \\
1.95 \\
1.1 \\
2.03 \\
2.19 \\
1 \cdot 57 \\
1.58 \\
1.19 \\
1.07 \\
1.05\end{array}$ \\
\hline
\end{tabular}

A dash (-) indicates incomplete urine collection.

* Operation within 24 hours of admission.

9 to 12 urinary 17-OHCS were less than $5 \mathrm{mg}$./24 hours. The degree of adrenal response to operation in Cases 1 to 8 as measured by urinary 17-OHCS parallels that expected from a standard corticotrophin stimulation test in the same age-group (author's findings to be published).

It will further be noted from Table 1 that a greater response was seen in those infants who were above their birth weight and in whom vomiting had been less severe though persistent and often over a longer period. The nature of block estimations for urinary steroid metabolites imposes restrictions on the further interpretation of results, but it will be seen that all the cases studied had a maximum excretion of 1-2 mg. $17-\mathrm{OHCS} / \mathrm{kg}$. on at least one day immediately following pyloromyotomy.

Aldosterone. The estimation of aldosterone by the method used involves three chromatographic systems. Small losses occur inevitably at various stages and it is necessary to measure the final

TABLE 2

URINARY EXCRETION OF FREE ALDOSTERONE IN CASES OF PYLORIC STENOSIS TREATED BY RAMSTEDT OPERATION

\begin{tabular}{|c|c|c|c|c|}
\hline \multirow{2}{*}{$\begin{array}{l}\text { Case } \\
\text { No. }\end{array}$} & \multirow{2}{*}{$\begin{array}{c}\text { Age } \\
\text { (wk.) }\end{array}$} & \multicolumn{3}{|c|}{ Urinary Aldosterone ( $\mu$ g.) } \\
\hline & & $\begin{array}{l}\text { 5-day } \\
\text { Total }\end{array}$ & Per Day & $\begin{array}{l}\text { Per Day } \\
\text { Corrected* }\end{array}$ \\
\hline $1-7$ & & \multicolumn{3}{|c|}{$\begin{array}{l}\text { Aldosterone not detected in single } \\
\text { 24-hour collections }\end{array}$} \\
\hline $\begin{array}{r}8 \\
9 \\
10 \\
11 \\
12 \\
13 \\
14 \\
15\end{array}$ & $\begin{array}{r}11 \\
6 \\
5 \\
5 \\
3 \\
10 \\
10 \\
7\end{array}$ & $\begin{array}{r}11 \cdot 5 \\
3.0 \\
2.0 \\
2.5 \\
3.0 \\
2.5 \\
\mathrm{Nil} \\
7.5\end{array}$ & $\begin{array}{l}2.3 \\
0.6 \\
0.4 \\
0.5 \\
0.6 \\
0.5 \\
\overline{1.5}\end{array}$ & $\begin{array}{l}3 \cdot 0 \\
1.0 \\
0 \cdot 6 \\
1 \cdot 0 \\
0 \cdot 8 \\
1 \cdot 1 \\
\frac{2 \cdot 7}{-}\end{array}$ \\
\hline
\end{tabular}

- Corrected according to individual recovery rates, which were from 43 to $75 \%$. percentage recovery. This is done by adding 10 m $\mu \mathrm{c}$ (millimicrocurie) $7-\mathrm{H}^{3}$-aldosterone to the urine before extraction and measuring the specific activity of an aliquot of the diacetate fraction. Another aliquot of this fraction, containing approximately the same amount of aldosterone as the standards to be used, is applied to the final chromatogram. Since the amount of aldosterone likely to be encountered was not known, the optimum aliquot applied to the final chromatograph was found by trial and error. In the early experiments, using 24-hour urine volumes, insignificantly different galvanometer readings for blank and fluorescence were obtained, even when using three-quarters of the aldosterone extract and with satisfactory recovery rates. Subsequently, the urine from each patient was bulked for 5 consecutive 24-hour periods and the daily excretion of free aldosterone taken as one-fifth of the total. Thus in only 7 of the 15 cases studied were reliable results obtained (Table 2). With recovery rates ranging from 43 to $75 \%$, the daily urinary excretion of free aldosterone ranged from 0.6 to $3 \mu \mathrm{g}$.

In Table 3 the calculated excretion of free aldosterone for the first 24-hour period in Cases 1-7 is shown.

TABLE 3

DAILY EXCRETION OF FREE ALDOSTERONE CALCULATED FROM RECOVERY RATES AND FLUORIMETER SENSITIVITY: TOTAL SINGLE 24-HOUR URINE SPECIMENS WERE EXTRACTED

\begin{tabular}{c|c|c|c}
\hline Case No. & \% Recovery & $\begin{array}{c}\text { Aliquot } \\
\text { of Extract } \\
\text { Applied }\end{array}$ & $\begin{array}{c}\text { Calculated Daily } \\
\text { Aldosterone } \\
\text { Excreted }(\mu \mathrm{g} .)\end{array}$ \\
\hline 1 & 54 & $0 \cdot 25$ & $0 \cdot 7$ \\
2 & 46 & $0 \cdot 25$ & $0 \cdot 8$ \\
3 & 60 & $0 \cdot 25$ & $0 \cdot 6$ \\
4 & 60 & $0 \cdot 5$ & $0 \cdot 3$ \\
5 & 58 & $0 \cdot 5$ & 0.3 \\
6 & 38 & $0 \cdot 75$ & $0 \cdot 35$ \\
7 & 62 & $0 \cdot 75$ & $0 \cdot 2$ \\
\hline
\end{tabular}


The average paper blank reading in each experiment was equivalent to $0.3 \mu \mathrm{g}$. aldosterone. Under test conditions a ratio of 1 to 4 for blank to aldosterone diacetate standard readings was consistently achieved by a minimum of $0.5 \mu \mathrm{g}$. amounts. While readings could be obtained for $0.1 \mu \mathrm{g}$. aldosterone diacetate a 'noise to signal' ratio of at least 1 to 4 was accepted as a better working rule. It will be seen from Tables 2 and 3 that the calculated daily excretion of free aldosterone and that actually found from bulked 5-day collections of urine are in agreement, and in each case the daily urinary excretion is $3 \mu \mathrm{g}$. or less.

The fractions of aldosterone appearing in the urine are free aldosterone, a $44-3$-oxoconjugate split by acid hydrolysis to yield free aldosterone, and a metabolite, tetrahydroaldosterone conjugated with glucuronic acid. Only the first two fractions are estimated by the method used, and together these fractions represent $5-15 \%$ of the total daily secretion of aldosterone by the adrenal cortex (Ross, 1959; Jones, Lloyd-Jones, Riondel, Tait, Tait, Bulbrook, and Greenwood, 1959). Thus daily secretion rates for aldosterone from 5-60 $\mu \mathrm{g}$. might be expected in infants up to 3 months of age.

Data on the aldosterone secretion rate for infants in this age-group are scant, but Degenhart, Visser, Wilmink, and Croughs (1965), using the double isotope dilution technique of Kliman and Peterson (1960), found the aldosterone secretion rate to be $60 \mu \mathrm{g} . / 24$ hours and $13 \cdot 5 \mu \mathrm{g}$. $/ 24$ hours in two infants, aged 2 months and 4 months respectively. After 4 to 6 days of salt deprivation the secretion rates were $100 \mu \mathrm{g} . / 24$ hours and $225 \mu \mathrm{g}$. $/ 24$ hours, respectively. In the present series all the urine collections for aldosterone estimation were made after the operation and during the period when an increased salt intake was encouraged. Indeed all cases received during the 3 days after operation more salt than would have been contained in standard milk feeds appropriate for the infants' ages. This might have depressed aldosterone production. It is clear that only small amounts of free aldosterone appear in the urine in this age-group and thus more helpful information will be obtained from the estimation or urinary tetrahydroaldosterone or from measurement of the aldosterone secretion rate.

\section{Summary}

The daily urinary 17-hydroxycorticosteroid (17OHCS) excretion was followed during the 5 days following pyloromyotomy in 12 infants with pyloric stenosis treated surgically, and attempts were made to estimate the daily excretion of free aldosterone in 15.

Higher urinary levels of 17-OHCS, of $5 \mathrm{mg}$. and more per day, were observed in infants who had a more favourable clinical assessment. In these vomiting had been less severe though of longer duration.

Insufficient free aldosterone appears in the urine to permit estimation on a single 24-hour specimen. Using total 5-day urine collections, a free aldosterone excretion of 0.6 to $3 \mu \mathrm{g}$. per day was found. It is suggested that measurement of daily aldosterone secretion rates or of urinary tetrahydroaldosterone would yield more helpful information.

I wish to thank Professor J. H. Hutchison for his encouragement in the preparation of this paper and for permission to publish these results from his patients. Thanks are also due to Professor Ivor H. Mills for his helpful criticism of this work, The sodium fluorimeter was made by Mr. D. Rowan, Regional Physics Department of the Western Regional Hospital Board. Part of the expense of these investigations was defrayed by the Rankin Funds of the University of Glasgow.

\section{REFERENCES}

Brooks, R. V. (1960). A method for the determination of aldosterone. Mem. Soc. Endocr., 8, 9.

Degenhart, H. J., Visser, H. K. A., Wilmink, R., and Croughs, W. (1965). Aldosterone and hydrocortisone secretion rates in infants and children with congenital adrenal hyperplasia indicating different degrees of 21-hydroxylation defects in salt-losers and non-salt-losers. Proc. Third Meeting of the European Pediatric Endocrinology Club held at Hamburg, 1964. Acta endocr. (Kbh.), Suppl. In the press.

Few, J. D. (1961). A method for the analysis of urinary 17-hydroxycorticosteroids. J. Endocr., 22, 31.

Jones, K. M., Lloyd-Jones, R., Riondel, A., Tait, J. F., Tait, S. A. S., Bulbrook, R. D., and Greenwood, F. C. (1959). Aldosterone secretion and metabolism in normal men and women and in pregnancy. Acta endocr. (Kbh.), 30, 321.

Kliman, B., and Peterson, R. E. (1960). Double isotope derivative assay of aldosterone in biological extracts. J. biol. Chem., 235, 1639.

Ross, E. J. (1959). Aldosterone in Clinical and Experimental Medicine, p. 24. Blackwell, Oxford.

Tyler, F. H., Schmidt, C. D., Eik-Nes, K., Brown, H., and Samuels, L. T. (1954). The role of the liver and the adrenal in producing elevated plasma 17-hydroxycorticosteroid levels in surgery. J. clin. Invest., 33, 1517. 